\title{
マンションにおける所有権・管理方法の初期設定が入居後の管理に及ぼす影響
}

\section{A STUDY OF EFFECTS OF INITIAL REGULATION REGARDING RIGHT OF OWNERSHIP AND MANAGEMENT SYSTEM ON MANAGEMENT OF CONDOMINIUM}

\author{
齊藤広子* \\ Hiroko SAITO
}

\begin{abstract}
This study aims at examining a better supply, planning and management system of condominium. We clarified effects of initial regulation regarding right of ownership and management system on management of condominium through 28 case studies. We find critical problems caused by inappropriate initial regulation regarding right of ownership and management system, in particular, (1) developers and former landowners tend to keep exclusive right of common space, for example community room, management room, parking spaces and so on. (2). Developers and former landowners tend to keep exclusive right of certain area of site. (3). Original rules tend to be advantageous for developers and former landowners in the right of management system, management expenses, votes and so on. It suggests an important of opening information regarding the right of ownership and management system, and proper initial regulation regarding the right of ownership and management system from the initial stage of management of the condominiums.
\end{abstract}

Keywords : Condominium, Management, Homeowners'Association, Ownership, Developer マンション 管理管理組合所有権分詮会社

\section{1. 研究の背景と目的}

\section{1 マンションの管理問題}

わが国においてマンション（区分所有型の集合住宅）は都市の主 要な形態となり、全国では約 1 割の人が、東京都や神奈川県では約 2 割の人がマンションに居住している。しかし、マンションではさ まざまな管理問題が発生していることから、かならずしも安定した 居住の場とはいえず、マンションそのものの存在を疑問視する意見 もある 1)。そのなかで、重要課題の一つであるマンション建替えに 対しては、建物の区分所有等に関する法律（区分所有法）を改正す るとともに、マンションの建替えの円滑化等に関する法律（マンシ ヨン建替え円滑化法）の創設で、マンションという私有財産に公的 支援を行うことで円滑な建替えを実現するスキームが整備された。 また、マンションの管理の適正化の推進に関する法律（マンション 管理適正化法）で、新しく国家資格としてのマンション管理士や管 理会社登録制度が創設され、国や地方公共団体の支援など、管理組 合を支援する体制が整備されつつある。つまり、マンションは私有 財産であるが、その円滑な管理には公的支援が少なからず必要とい う姿勢がある。

しかし、根本的に求められる姿勢は、マンションの管理問題の発 生を予防することである。マンションの管理問題は発生すると解決
が困難であることが多く、生活にかかわることであるが故に裁判や 金銭的解決になじまないものが多い。そこで、問題発生を予防する ことが第一になる。そのため、実際に起こっている管理問題を把握 し、そもそもの原因はどこにあるのか、どのようにすれば問題が未 然に防げたのか、その方策を考えることが重要になる。つまり、マ ンションの本格的供給から約 40 年経った現在においても変わらず 生じる管理問題を把握し、そのなかでも、区分所有者や管理担当者 の一般的な知識や努力の不足を超え、裁判でも解決しにくい問題の 発生予防を考えることはマンションを安心して居住できる場とする ために必要なことである。

\section{2 分譲時の所有権・管理方法の設定に原因がある管理問題}

管理問題のなかに、分銥時にマンションの所有権・管理方法の初 期設定が適正にされないために生じるものがある。これらの問題が 社会問題化したのは昭和 40 年代後半からである。例えば、分譲会 社が駐車場部分の土地所有権を留保し分譲する方法や、駐車場の専 用使用権が分譲されるなどである。昭和 54 年にこのような分譲時 の設定・分譲方法はこのましくないとの建設省の通達が出され、か つ宅地建物取引業法における重要事項説明のなかでも説明すること が位置付けられた。昭和 58 年の区分所有法改正の時点でもこの点 は議論となったが、基本的には契約自由の原則に従うべきだと考え 
られた。その為、その後この問題は基本的には裁判で争われている。

上記の事例のように、通達が出されたにもかかわらず、ある特定 の所有者に有利な条件を設定する、一部の共用部分の所有権を保留 する、駐車場の専用使用権を販売するなど、管理組合による円滑な 共同管理を阻害する分譲方法がある。裁判事例では、敷地に関して は、建物水平投影部分のみが敷地となり道路に接していない事例、 駐車場スペースを分譲会社が保留している事例がある。また、共用 部分に関する問題では、管理人室を分譲会社が所有している事例、 ピロティに分譲会社が事務所を作った事例、原始規約で分譲会社に よる駐車場や看板設置の無料使用等の規定がある事例がある。いず れもわが国のマンション管理の原則である、民主的な管理組合の運 営を阻害するものとして、マンション購入者から是正を訴えたもの であるが、上記の契約自由原則により必ずしも購入者が勝訴とはな っていない2。

\section{3 上記問題に対する既に行われた行政対応}

こうした問題に対して、マンション購入時の重要事項説明内容の 充実及び国による通達などでの指導が行われてきた。具体的には、 昭和 54 年 (1979 年) の「民間分譲中高層共同住宅 (マンション) の施工管理になどの徹底、取引の公平性の確保及び管理の適正化に ついて」の関係団体への通達、それを受けて昭和 55 年 (1980 年) の宅地建物取引業法の改正による敷地の権利の種類や内容、共用部 分の䈖囲、専用使用権についての説明項目の追加、平成 4 年 (1992 年）の「中層分銥共同住宅（マンション）に倸る管理の適正化及び 取引の公正化の確保について」で、管理規約及び委託契約書の標準 版との相違を説明することを関係団体に通達した。さらに、平成 11 年 $(1999$ 年)には宅地建物取引業法の改正により、重要事項説明で 管理費や修繥積立金を特定の人に対して減免する場合には説明する ことが加わっている。

また、これらの問題については、マンション管理適正化法の創設 および区分所有法改正時にも検討された ${ }^{3)}$ 。しかし、マンション管 理適正化法創設時にはこの問題の全国実態が把握できず、分譲会社 の設計図書引渡し責任のみが条文化された。平成 14 年（2002 年） の区分所有法改正時では、区分所有法は区分所有者間の利害調整や 各区分所有者と管理組合との関係、各戸（専有部分）と全体（共用 部分）との関係、管理組合組織運営上のルールであり、消費者保護 という視点を区分所有法に盛り込むことは適切ではないのかという 議論が行われた。しかし、結果として「規約の適正化」が条文とし て加わり、消費者保護の視点からみたマンション管理の適正化に前 淮がみられた4)。

しかしながら、現状ではマンション購入者がそれらを把握し、将 来起こり得る管理問題を予想し契約条件を検討することは難しい。 かつマンションで入居時に初期設定された所有権・管理方法（管理 規約など）は簡単に変更できるものではない。

また、マンションは、戸建て住宅よりも複雑な所有形態であり、 かつ、将来問題が生じた場合には個人レベルでの解決困難なものも 多い。ゆえに、戸建て住宅よりもより一首消費者保護の視点からの 情報開示が求められるが、現状ではマンション分譲時に情報の非対 称性がある。住宅などの不動産売買の際、契約成立までに不動産業 者・仲介業者の宅地建物取引主任者が、購入者の意思決定に重要な 影響を及ぼす項目について重要事項説明として説明することになつ
ているが、その内容は制限的であり、素人にはわかりにくい。さら に多くの場合は契約直前に行われ、実態として消費者はそれらの情 報を踏まえ意思決定を行っているとはいいがたい。

そこで第一に入居後のマンション管理を円滑に行うには新規供給 時である分譲時から消費者保護の視点で管理問題をなくす、少なく する条件を整備した所有権·管理方法を設定することが必要である。

第二にマンション分諼において所有権・管理方法も含めた適正な 情報の開示が必要である。

\section{4 研究の問題意識と目的}

マンションの分譲方法、特に所有権・管理方法の初期設定はその 後の居住や管理に大きな影響を与える。しかし、わが国ではその適 正化のための積極的取り組みはほとんどない。

わが国と同じようなマンション管理方法をとるアメリカ・カリフ オルニア州では、入居後の管理を内滑に行うといった視点から、州 の不動産局が初期の管理方法の指導、その情報公開としてパブリッ クレポートを発行する ${ }^{5}$ 。

わが国にもこうした制度が必要ではないか。つまり、区分所有の 所有形態をとるマンションは、個人の所有権が併存し、かつそれを 包み込む形で全体の共有関係をもった、民と民の所有関係の集合体 であるが、それらの管理を円滑に行うには初期設定から畩境整備を 行う必要があるのではないかという問題意識である。

そこで、こうした制度を検討するにあたり、所有権や管理方法の 初期設定が入居後の居住や管理にどのように影響を及ほすのか、入 居後問題となる初期設定がどのように行われているのか、また、国 からの通達が反映されているのかを明らかにする。

\section{2. マンションの所有権・管理方法の初期設定}

2.1 マンションの所有権・管理方法とその初期設定

マンションの所有権と管理方法は、現在及び将来についてマンシ ヨンにおける快適な居住環境と財産性を維持する役割がある。その ため、所有権や管理方法は、長期にわたり継続的に、区分所有者相 互間の利益が衡平なものとして設定されることが必要である。所有 権および管理方法の初期設定とは、次の項目が分諥会社により分譲 時に設定されたものをいう。所有権に関しては、敷地の権利、共用 部分と専有部分の区分、管理方法については、管理費・修䋹積立金 の負担割合、議決権の割合、管理会社、管理者等の設定など、主に は管理規約の内容となる。それは、マンションの所有権及びその利 用と管理方法については、区分所有法の強行規定以外は、各マンシ ヨン内のルールとして、規約で規定できるからである。

\section{2 初期設定がその後の管理に影響を及ぼす理由}

マンションでは入居後区分所有者が自主的に集まり、管理組合を 設立し、一から規約をつくることが難しシルん、管理組合の設立、 設立総会、原始規約（はじめの管理規約）を分譲時に分譲会社が主 導し、そのなかで管理者、管理費や修繕積立金の費用負担方法、管 理会社と業務の委託内容等を設定することが多い。しかし、一度設 定された規定を入居後区分所有者は変更しにくい。管理方法の変更 には区分所有者及び議决権の $3 / 4$ 以上の同意が必要となるからであ る。

不十分な初期設定による問題では、修繥積立金が不足して、修繕 が実施できない等がある。しかし、この問題は関係者の利害が一致 
表-1. 調查対象マンションの特徵

\begin{tabular}{|c|c|c|c|c|c|}
\hline & & \multicolumn{2}{|c|}{ 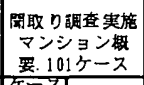 } & \multicolumn{2}{|c|}{$\begin{array}{l}\text { 問題のあったた } \\
\text { マンショシ概 } \\
\text { 要. } 28 \text { ケース } \\
\end{array}$} \\
\hline & & 数 & 構成率 & $\begin{array}{l}5-\lambda \\
\text { 数 }\end{array}$ & 構成率 \\
\hline \multirow{8}{*}{$\frac{\text { 立 }}{\text { 地 }}$} & 北海道 & 7 & 0.07 & 2 & 0.07 \\
\hline & 東北 & 12 & 0.12 & 4 & 0.14 \\
\hline & 関東 & 20 & 0.20 & 5 & 0.18 \\
\hline & 北陸 & 7 & 0.07 & 3 & 0.11 \\
\hline & 東海 & 11 & 0.11 & 3 & 0.1 .1 \\
\hline & |近娀 & 17 & 0.17 & 0 & 0.00 \\
\hline & 中国・四国 & 15 & 0.15 & 5 & 0.18 \\
\hline & 九州 & 12 & 0.12 & 5 & 0.18 \\
\hline \multirow{5}{*}{$\begin{array}{l}\text { 努 } \\
\text { 年 }\end{array}$} & 1965 1974年 & 28 & 0.28 & 10 & 0.36 \\
\hline & 1975～1984年 & 39 & 0.39 & 11 & 0.39 \\
\hline & 1985 1989年 & 18 & 0.18 & 3 & 0.11 \\
\hline & 1990 1994年 & 9 & 0.09 & 2 & 0.07 \\
\hline & 1995年〜 & 7 & 0.07 & 2 & 0.07 \\
\hline \multirow{3}{*}{$\begin{array}{l}\text { 位給 } \\
\text { 主 }\end{array}$} & 公的 (公団·公社) & 23 & 0.23 & 1 & 0.04 \\
\hline & 底間（全国） & 31 & 0.31 & 6 & 0.21 \\
\hline & 民間（地元） & 47 & 0.47 & 21 & 0.75 \\
\hline \multirow{7}{*}{$\begin{array}{l}\text { 戸 } \\
\text { 数 }\end{array}$} & 20戸以下 & 4 & 0.04 & 1 & 0.04 \\
\hline & 21～29戸 & $?$ & 0.07 & 3 & 0.11 \\
\hline & $30 \sim 50$ 戸 & 20 & 0.20 & 7 & 0.25 \\
\hline & $51 \sim 100 戸$ & 28 & 0.28 & 13 & 0.46 \\
\hline & 101 200戸 & 17 & 0.17 & 3 & 0.11 \\
\hline & $201 \sim 500$ 戸 & 15 & 0.15 & 1 & 0.04 \\
\hline & 501戸〜 & 10 & 0.10 & 0 & 0.00 \\
\hline
\end{tabular}

しやすい、規約や登記の変更を必要としない ため、相対的には問題を解消しやすい構造を もっていること ${ }^{6)}$ や、最近では以下の取り組 みから是正される方向にある。

2. 3 マンション管理方法の初期設定適正化のための取り組み

現在、初期設定適正化のために二つの自主基準・誘導施策が ある。第一は分埕会社自らの自主基準 フである。第二は住宅金 融公庫の融資条件としての誘導基凖 》である。しかし、それら の対象となるマンションは限定的で、内容も修繥積立金の設定金額、 修䋹計画の立案、管理規約の標準管理規約への準拠等であり、部分 的である。その為、全てのマンションが対象となり、所有権も含め た管理方法の初期設定の適正化を規制・誘導する仕組みが現在わが 国には存在していない 9)。

\section{3. 管理方法等の初期設定が管理に及ぼす影箁の把握方法}

所有権や管理方法の初期設定が入居後の居住や管理にどのように 影響を及ぼすのか、また入居後問題となる初期設定がどのように行 われているのかを、管理組合への聞取り調查から明らかにする。調 査対象マンションは管理組合活動実態を詳細に聞取りできる全国 101 のマンションを選出した。その選出には、(1)対象マンションに 訲問し、区分所有者複数人に管理についての話を $2 \sim 3$ 時間聞けるこ

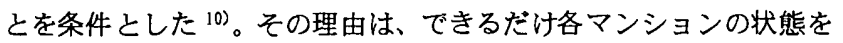
正確に詳細に把握すること、また管理組合にとっては負の情報の提 供となる場合もあるので、直接顔をみることで相互に信頼関係を築 けると考えたからである。(2)対象地域を首都圈のみや三大都市圈に 偏りのないようにした。全国としたのは、著者は以前よりマンショ ン管理の事態は地域により大きく異なることを認識しているからで ある ${ }^{11}$ 。そのため、全国のマンション管理組合協議会・連絡会を通 じて対象マンションを選定した ${ }^{12)}$ 。また、選定条件として101 のマ ンションは、「初期設定に問題がある」ことは条件としなかった。そ の理由は、特殊解を探すというよりも、一般解として全国のマンシ

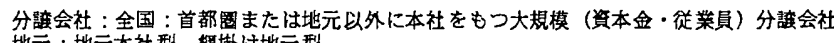
地元: 地完本社型能掛门地元型

管理会社：地主：元地主管理、系列会社 ; 分撞会社の系列・小会社、分諡会社とおなしまた は系列に㜊掛门

列期の所有管理状態; 該当するものに○、会社所有：分淕会社又は元地主が区分所有してい ろ、会社管理：分镇会社又は元地主管理、組合なし：管理組合なし、大口所有：大口所有者

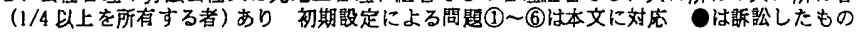

ヨンのなかでどの程度、どのような問題があるかを把握するためで ある。対象 101 マンションについて、現地で聞取り調查を実施した 結果、28 マンションに初期設定に問題がみられた（表-1）。調査の 実施は平成 $12(2000)$ 年 7 月から平成 14(2002) 年 3月までである。 調查対象マンションは区分所有者自己居住用マンションである ${ }^{13)}$

(表-2)。なお、問題があったマンションの特徵は、立地は大都市圈 では相対的に少なく、地方圈が多い。分埕会社は地元型不動産会社 により分埕されたもので、供給年は古いものが相対的に多い。

\section{4. 問題の事例}

\section{1 問題の分類}

聞取り調査を通じて把握した所有権や管理方法の初期設定は、入 居後に四タイプの当事者間の利害対立問題として現れている。第一 にはマンション（管理組合）と分講会社との利害対立、第二は等価 交換手法をもちいたマンションの元地主（区分所有者）と他の区分 所有者との利害対立、第三はマンション（管理組合）と管理会社と の利害対立、第四は区分所有者間の利害対立である。

第一の利害対立は、分埕会社が有利となる、管理費・修綁積立金、 駐車場の使用権、議决権、管理会社、管理者、共用部分と専有部分 の設定等が行われることによる問題である。第二の利害対立は、等 価交換手法をもちいたマンションの元地主が有利となる、管理費 ・ 修繥積立金、駐車場の使用権、議決権、管理会社、管理者、共用部 分と専有部分の設定等が行われることによる問題である。第三の利 
害対立は管理会社に有利な初期設定が行われることによる問題であ る。これらは上記の第一.二の問題と連動することが多い。第四の 利害対立は駐車場専用使用権をめぐる問題である。

\section{2 問題事例}

入居後、居住や管理上の問題を生み出す所有権・管理方法の初期 設定は次の六つに分類できる。

所有権に関しては、(1)共用部分の設定、(2)敷地の権利関係の設定、 (3)駐車場の権利関係の設定、管理方法に関しては、(4)元地主や管理 会社による管理、(5)管理方法（特に管理費など）の設定、(6)共用部 分の専用使用である。以下に(1)〜6に従い問題事例を分析する。

\section{(1) 共用部分の設定（表-3）}

共同で利用すべき空間であるにもかかわらず、分譲会社や元地主 の専有部分として設定されている場合がある。例えば、ピロティ、 管理人室、集会室、廊下、電気室、ポンプ室、受付、駐車場である。 この場合にはこれらの施設を居住者が持続的に使えない状態となる、 あるいは、そうした可能性があり、居住者は不安となっている。共 用部分には法定共用部分と規約共用部分がある。法定共用部分は登 記ができず、規約共用部分は登記をして第三者に対抗できることに なる。上記の場合、廊下、電気室、ポンプ室は法定共用部分と解さ れる。管理人室、駐車場、ピロティなどが共用部分かどうかをめぐ る裁判事例は多々あるが、全てが共用部分と認められているわけで はない。そのため、登記が第三者対抗要件となるが、表-2 表記の No. 1. 6. 11.12.28 のマンションでは、分諼会社や元地主が尃有部分 として登記をし、規約共用部分とは登記していなかった。そのため No. 1 マンションでは、裁判により共用の廊下を共用部分として認め られるに至っている。共用部分とも専有部分とも登記をしていない 事例はNo. 21・22 である。No. 22 は、集会室の使用をめぐり、管理組 合と元地主とが裁判で争い、管理組合の使用が認められた。No. 21 は管理人室を所有していた分虽会社が倒産となり、その後それを譲 り受けたC会社も倒産となった。それで管理人室が競売となり、第 三者に購入される可能性が生まれたため、管理組合が入札し購入し た。なお、No. 21 も裁判中であったが、その過程でC会社が倒産し たための対応である。

上記のように、訴訟する例は必ずしも多くわけではない。かつ、 訴訟にも時間と費用がかかる。また、必ずしも管理人室などが共用 部分と認められるとは限らない。

なお、№. 28 ではピロティに駐車スペースをつくり登記した。分 譲会社は専有部分の面積が増加したことにより、議決権の増加を主 張した。その結果、分襄会社が $1 / 4$ 以上の議決権を所有する結果と なり、管理運営に問題が生じている。

こうした問題が生じているマンションの特徵として、元地主が等 価交換型により建設したマンション（No.1.6.11.12.22.）で、元地 主または分譲会社が尃有部分を所有し、管理を行っている。こうし た状態に依存し、管理組合が実質的に機能していなかったマンショ ンである。No. 28 は賃貸マンションを区分所有にして分埕したもの である。また、マンション供給年の古いもの、つまり、各地域でマ ンション管理の基礎知識がなかったころに供給されたものである。

\section{(2) 敷地の権利関係の設定（表-4）}

分譲会社や元地主が敷地を留保するケースがある。マンションの 敷地の多くは所有権であり、区分所有者の共有となる。敷地利用権
の形態は二つあり、建物が所在する土地（物理的敷地・法的敷地） と、規約により敷地とする土地（規約敷地）である。区分所有者が 建物及び建物が所在する土地と一体として管理または使用する庭、 道路、その他の土地であり、建物直下の土地ではないが敷地に入っ ている 1 筆の土地以外は、規約で「敷地」にしなければいけない（区 分所有法第 5 条)。また、建築確認時に申請した敷地が氷久にマン ションの敷地となることを担保する仕組みがない。そのため、敷地 を 2 筆に分け、将来にわたり収入源となる駐車場部分を分埕会社や 元地主が所有している（No.11.18.21）。その他、一般消費者が自分 のマンションの敷地を把握することは難しいために、建築確認敷地 と登記褡地が不一致となっていた事例（No.12）や、マンション敷 地を分襄会社や元地主が留保するケースがある（No.2.24）。その結 果、既存不適格であるマンションもあり、增築や建替え等の更新時 には大きな問題となる可能性があり、管理組合は問題としている。

\section{表-3. 共用部分の設定による問題事例}

○共用廊下が尃有部分になった

·元地主が 1 階と地下階を所有していた。入居後 13 年間は管理組合もなく、 元地主が管理をしていた。共用部分の一部（1 階中廊下部分）を元地主が 勝手に区切り、専有部分として登記をし、それを売却し出ていった。管理 费や修繥積立金、大規模修䌜費用も支払わない。その後裁判にて解決した (共用部分にみとめられた) (No1; 表-2 表記 マンションNo1、以下同様)。 ○管理人室や集会室が元地主所有になっている

・地主が地下階と1〜3 階までを所有している。入居後 15 年間は管理組合 もなく、元地主が管理をしていた。ポンプ室、電気室、受付、集会室、駐 車場を元地主が所有している。話し合い中である（No 6)。

・集会室のようなスペースが屋上にある。これを元地主が専用の応接室と して使っていた。元地主と管理組合でこのスペースの所有・利用権をめく る裁判をした。結果「元地主のものではない」という結果になり、現在集 会室として管理組合が利用している（No 22）。

○管理人室を元地主が所有する

・元地主が長い間管理をし、管理人室を所有・尃用していた。その後自力 管理に切替ると、管理人室がなくなり、元地主所有の倉庫となった (No 11)。 ・分䧿会社が倒産し、分培会社が所有していた 1 階駐車場全てがC社に所 有権がかわっ。C社は駐車場の中央部にある管理人室の所有権を分說会 社から購入したと主張した。C会社が倒産し、それが競売になったので管 理組合で落札した（(No 21)。

OI 階全てが分培会社所有である

・1 階全てが分湓会社所有になっている。道路からピロティを通り、各住

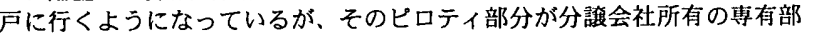
分であった。気が付いて分初会社と交涉をし、ピロティ部分を管理組合で 買い取り、その一部に集会所を作った。(No 12)。

-1 階のピロティ部分を分釖会社（元地主）が駐車場にした。かつその分 の議決権の增加を主張した（No 28）。

\section{表-4. 敷地の所有関係の設定による問題事例}

○分譲会社や元地主が土地を留保、または持分を留保する

・入居後 15 年間分雜会社の子会社が管理をしていた。しかし実際はそこか ら再委託を受けたA会社が管理を行い、管理組合はなかった。その後、管 理組合を設立し、直接A社と契約をすることになり、はじめて団地内通路 が全て分哜会社所有であることが判明した。将来の建替え計画は土地を 1 筆としてつくっている。管理組合を法人にして分譲会社所有の土地の所有 権を移転した(No 2)。

・区分所有者の土地持分をすべて合計しても持分が1（100/100）になら ない。調查の結果、分識会社が持分を留保していた（No 24）。

○元地主が土地を分筆所有する ・駐車場敷地を分筆し元地主が所有している（No 11.18.21）。 ○非接道敷地になっていた

・公道に面していない敷地である。開発の際は隣のマンションと一緒に 2 槽一括して申請し許可を受けたが、現在は 2 棟別々の敷地で別の管理組合 である。またその間に別の会社所有の土地がある。そのため、1 楝は非接 道数地となり、現在接道するために土地購入を検討している。買い取った 部分の所有名義は理事長個人とする予定であるが、不安ではある（No I2）。

○地上権設定の条件が地主に有利である

・地上権が設定されたマンションで、地代の算出は「每年 7 月 1 日現在表 示の土地路線評仿額を基礎額とし、前年度よりそれが減額している場合は 前年度地代を据え置き」が契約条件である。バブル時にあがった地代を現 在さげることができない（№ 17）。 
No.17 はマンションの 1 部に地上権が設定されているが、その契 約が地主に有利となっている。

教地の権利関係については、全国的に広く見られる。本調查では 国の通達後に供給されたマンションでは問題は見られなかった。

(3) 駐車場の権利関係の設定（表-5）

教地や建物の一部を分譲会社や元地主が留保し、駐車場の利用権 利を排他的に支配している(No.4.5.6.8.11.19.21.22)。この場合に、 将来にわたり、マンションの共用部分として駐車場が使えるかが問 題となる。実際に、駐車場がなくなり（No.19）、事務所となった事 例（No. 5）や貨貸住宅となった事例（No. 22）がある。他にも駐車 場の権利関係に関する問題は多い。元地主・分譫会社が駐車場を専 用し、使用料を支払わない（No. 7.16）事例がある。

駐車場としての利用権（専用使用権）が分譲される例がある （No. 10.21.27）。これらの問題について、昭和 54 年（1979 年）の 通達では「好ましくない」と指摘された。しかし、こうした問題の その後の裁判では、最高裁で「好ましくないが、分埕は有効である」 という結論であり、未だこういった販売方法がとられている。№. 27 マンションでは 1991 年に分譲され、駐車場の専用使用権が分埕され ていたことから、その是正をめぐり組合員同士の裁判になっている。

駐車場が区分所有の対象となり、分譲されている事例がある (No.14.15.24)。駐車場が区分所有として分譲されている場合に、 その所有者を住戸所有者に限定する規定はなく、駐車場のみを所有 する区分所有者が存在することを防ぐ仕組みがない。他に、特定の 人が所有する事例、はじめから近隣駐車場を借りることが設定され ている事例（No. 23）などがあり、マンション居住に必要な施設を居 住者が永続的に使用できる体制が整備されていない。

これらのマンションは、地元型会社による分培や筑年数が古いも のに限定されない。また、地域も全国的に広がっている。国による 通達が出された後も、こうした形式の分䛨、特に駐車場の専用使用 権の分譲が行われている。

\section{(4) 分譲会社・元地主による管理（表-6）}

元地主・分襄会社が入居当初から管理を行い、管理組合がない場 合の問題がある (No. 1. 6. 7. 10.11.12.16.18.19.21.22.25.28)。具体 的には、区分所有者に管理費や修緗積立金の報告がない、管理会社 や管理人が全て業務を判断し、執行する。工事の発注も管理人が独 自に行い、修績費用がたりなくなると、修綪積立金の值上げを行う などがある(№ 9)。

分譲会社が原始規約の中で、管理会社を決めている（No 9.10）、 または管理会社や管理人の裁量を大きくしている（№ 10.26.27）。

区分所有者は長い間、元地主・分輁会社（系列の管理会社を含む） に管理をまかせ、主体性が育ちにくくなり、区分所有者が梯々な問 題に気が付いたときには解決が困難な状態となっている。

逆に分誩会社が原始管理規約の準備もなく、組合設立の支援も一 切ない場合がある（No.13.25）。この点も昭和 54 年（1979 年）の 通達で分埕会社に「管理組合設立の勧奖」が行われたが、その後分 襄のマンションでも問題が見られる。

分埕会社・元地主による管理及び管理組合設立などの支援が行わ れない問題は、マンションの立地や供給年にかかわらずみられる。

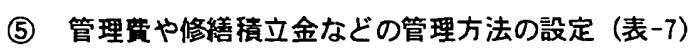

分講会社所有部分や元地主所有部分の管理費や修䋹積立金が他に
表-5.駐車場の権利関係の設定による問題事例

○分譲会社・元地主が駐車場を所有している（屋内駐車場）

・入居開始以来分譫会社がピロティ部分の駐車場を全て所有し、それを管 理組合が借りている (No 8)。

・元地主が屋内機械式駐車場を所有し、それを現在 B社が買取り所有した。 B 社は現在マンション全体の住戸の半分以上を所有している(№ 4)。 ・1 階のピロティ部分を分譲会社（元地主）が駐車場にした（No 28）。

・地下 1 階に駐車場があるが、全て元地主が所有している (No 6)。

○分譔会社・元地主が駐車場を所有している（土地分簕型）

・元地主が駐車場部分の土地を分筆して所有している。マンション居住者 は元地主から軴車場を借りている（No 11）。

・元地主が駐車場部分の土地を分筆し所有していた。マンション居住者は マンションの駐車場だと思っていた。ところが元地主に相続が起こり、そ の土地を物納した。結果駐車場がなくなった（No 19）。

・分誶会社が駐車埸 50 台の内、40台を所有し、残り 10 台を販売していた。 40 台分の土地は分誶会社が所有していた。はじめは管理組合も自治会もな かったので、まず管理組合をつくり、10 台分の権利を管理組合が買い戻し た。その後分埕会社が不渡りを出し倒産し、分虽会社所有の土地（駐車ス ペース）がC社に購入された。駐車スペースのなかにあった管理人室は未 登記であったため、C社は管理人室と駐車スペースを登記しようとした。 しかしC社も倒産し競売物件になった為、管理組合で入札した（No 21）。

○元地主が駐車場を所有していたが、その部分に賃貸住宅が建設された ・マンションの駐車場を元地主が所有していた。それはマンションに隣接 しマンションの敷地にみえ、居住者は沓久にその駐車場を賃貸で利用でき る条件であった。ところが築 20 年時点で駐車場が貨貸住宅になった。現在 マンションに駐車場はない(№ 22)。

○分埕会社が駐車場を所有していたが、そこを販売し、事務所になった ・分譲会社が 1 階の駐車場を所有していた。分榱会社の専有部分とし、マ ンション居住者に貸していた。しかし到座したためにD社に売り、現在は 駐車場がなくなり、事務所となっている（№ 5)。

○元地主が駐車場を専用使用し、使用料は不払いである

・筑 20 年以上になるが、元地主が店赤前の駐車場を専用使用し、ずっと使 用料を支払わない。管理費も払わない。入居後 5 年間管理組合はなく、分 譲会社がずっと管理をしていた（No 16）。

・分誶会社がマンションの駐車場全て 8 台分を店舗の来客用駐車場として 無料で使用している (No 7)。

○駐車場の専用使用権が分譲されている

・駐車場がすべて分譲されている。現在、区分所有者が退去する際には管 理組合に使用権を返却してもらうようにしている(No 10)。

・駐車場の専用使用権が販売されていた。これを規約改正し、区分所有者 1 代限りのものとした（次に販売できない）。これを不当と考えた区分所有 者が裁判を起こした（No 27）。

○屋内駐車場が分埕されている

・はじめは 1 階にスーパーが入っていた。しかし、立地が德く流行ず閉店 した。そのスペースを駐車場にし、2 階の事務所を分誶する際に駐車場付 で分識した（No24）。

・駐車場及びトランクルームが専有部分として分境している（No 14）。 - 駐車場が尃有部分として分䜖されている (No 15)。

○近隣の貨貸拄車場を利用することが前提となっている。

・地方都市で車の必要な立地であるマンションで、敷地内には駐車場が少 なく近隣駐車場を借りることが前提となっている(No 23)。

\section{表-6. 元地主・分强会社による管理等の問題事例}

\section{○元地主・分誶会社が管理する}

・元地主・分䜅会社がずっと管理をしていた。管理組合がなく、機能していな かった (No1.6.7.11.12.16.18.19.21.22.25.28)。

. 10 年間は管理組合はなく, 当初設定された管理会社が管理をしていた。管理 会社の管理人が近隣とのトラブルなどを起こし自力管理にした（№ 10）。

○規約などが末設定で、準備もない

・管理組合も規約も何も分誶会社から設定されていない（No.13.25）。

○管理会社が当初から設定され、変更できない

・原始規約のなかで管理業務は分譫会社に委託するという規定がある。管理会 社を変えることができない。管理会社（分譲会社）が理事会の司会をし、マ ンションの広報誌も管理組合に相談もなく作成し、配付する。工事の発注も 行い、そのため修繥積立金が不足すると一方的に值上けを要求する (No 9)。 ・原始規約の中で管理会社の裁量が大きくなるように設定していた（No 27）。 ○管理者に管理人が設定されている

・入居 10 年間分襄会社が管理をし、分誶会社の社員が 1 住戸に住み、管理人 をしていた。原始規約で管理者は管理人となっていた（No 26）。

比べ、低く設定されている事例がある（No 22）。管理費や修繥積立 金は専有面積に応じることが原則であるが、その設定になってていな い。また、管理費が末払いである場合がある（No. 18.25.27、No.7 は表-9)。一般的にはマンション分講の䟢に、分譲会社によって規約 
等（管理会社及びそこへの委託内容などを含む）が設定され、それ を購入者が個別に同意することで成立する仕組みがとられる。しか し、その初期設定が分襄会社やその系列の管理会社、元地主に有利 になっていることを一般消費者が理解しにくいからである。一旦成 立した規約等の変更には $3 / 4$ 以上の合意が必要であり、改正は難し い。かつ、本人の承諾なく、值上げや金額を決めることが必ずしも 有効とならないからである。このように規約の不利な内容を改正し ようにも、分睓会社や元地主の所有スペースが多く、議决権が多い ために規約改正の $3 / 4$ 以上の多数が得られない、または「利害関係 のあるものの承諾」という区分所有法の規定がはばみ、円滑に規約 改正が行えない（№22、No 7 は表-9.)。

また、大口所有者が存在することから、規約の改正以外でも、管 理組合の運営を円滑に行えない（No 3.4.19）、大規模修繙の実施が できないなどの問題が生じている（No.28。表-8）。

これらはマンションの供給年にかかわらず見られる。

\section{表-7. 管理髑等の設定などの管理方法の設定の問題專例}

\section{O店辞管理費を払わない（元地主所有分） \\ ・店舒部分の管理費を分培会社が支払わない（№ 18）。 \\ ○店甜管理費の設定が有利である(元地主所有分)}

・元地主の所有部分（店哺 I 階〜 3 階）の管理費加住居部分の $80 \%$ に原始 規約で設定されていた（住居部分は月 $\mathrm{m}^{2}$ 当り $100 \mathrm{HR}$ 対し、店䎋部分は 80 円)。元地主が当初から管理を行い、管理組合もなかった。その後管理組合 をつくり、裁判を行った。裁判の結果、管理費は店舗と住居は同額となっ た。元地主の所有分が多いため、規約改正が图難である（№ 22）。

○分蟀会社が未販売住戸の管理費等を支払わない

・入居 5 年になりようやく管理組合ができた。それまでは分誶会社が管理 費を集め、全て管理を行っていた。管理規䄪もなく、分䜅会社は壳れ残り 住戸の管理費を支払っていなかった（No 25）。

・分讙会社がマンションの販壳途中で倒産した。建設資金として全 73 戸の うち 38 戸を建設会社に渡した。建設会社は 2 年間住戸を販売せずそのまま にし、その後値引きをして販壳した。その間の管理負・修熺皘立金も支払 っていない。そのため、入居時期の異なる先・居住租と後・居住組で対立 意識がある(№ 27)。

○大口所有者や貨貸化により管理荤営に支遥がある

元地主が 1/4 以上を所有している。㲎営が難しい（No 19）

・元地主が半数以上の住戸を所有し、現在それをA社が買い取り所有して いる (No 4)。

-現在入居約 15 年で貨貨察が約 4 割である。当初よりある会社が 1 割以上 所有し、貨貸化が加速している (No 3)。

\section{表-8. 大口所有者の存在により管理組合の㞄営が图難な專例}

No 28 マンション: 熊本県熊本市・1973 年入居開始・全 38 区画・事務所 $6 、$ 住居 30 。ビル娻と住居橧の二棟になっている。ビル棟部分と住居掼 1 階部分 と1 住戸を分培会社加所有。

・当初は貨貸アパートとビルであったものを、1 区画つつ順に販壳していった (区分所有化)。管理組合は 20 年間なく、分誶会社が管理をし、その間会 計報告もなかった。場当たり的な修佯を実施し、その都度一時金が集めら れた。

-1 階ピロティを然然仕切り駐車場とし、その区画分の踫決権增加を分㜔会社 は主張した。

・筑 30 年になるが、今まて大規模修繥をしていない。管理者責任もあるので

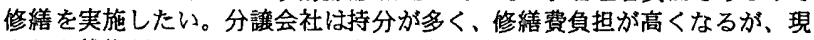
在経営状態がよくないのでその負担が喛しく、修結実施に同意をしない。 そのため、修㱍が実施できない。修䋨の決讙を取るのが難しく、行政から の修艂钬告を望んでいる ${ }^{14)}$

\section{（6) 共用部分の夏用使用（表-9）}

共用部分が専用使用されている事例がある。分諒会社や元地主が 駐車スペースや、敷地や塔屋に看板の設置や、管理人室など専用使 用し、使用料を支払わない（表-9）。また、元地主・分譲会社による 駐車場の専用使用や（表-5. NNo.16）や集会室の専用使用の問題があ る（表-3. No. 22）。

こうした問題は先の(1)〜5)の問題と関連し生じることが多い。

\section{表-9. 共用部分の專用使用の事例}

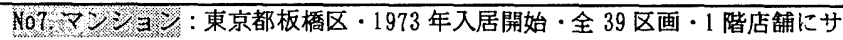
ウナと理骨店、スナック（その後、コインランドリー）。1 階店舗と 2 階住戸 2 戸を分譲会社が所有。

・分誶会社がマンションの駐車場全て 8 台分を店赫の来客用駐車場として無 料で使用。

・屋上塔屋と非常湝段に無鰂で看板を設置、屋上や 2 階スペース、その他做 地空きスペースに営業用設備・施設を設置し、無料使用。

・管理は分譲会社管理。分境会社は 1 階店哺部分の管理費を未払い。

原始規約に・特定個所の専用使用権とし、本建物のうち、広告物などの設 置のための外壁の一部、屋上や塔屋外壁の使用権は分䜋会社が保有する。敨 地の使用権は分埕会社が保有する」とあり、分变時の売買㛃約書にも同様の 規定があった。また、「規約の改無は全員の書面による合意」とある。これを 根拠に分誶会社が無償で使用し、区分所有者にとって不利な規約改正ができ ない状態であった。管理組合は入居 5 年後から 20 年以上、当初の原始規約の 是正を求め裁判を続けてきた。

Nol 8. マンシヨン: 三重県四日市市・1974 年入居開始・全 58 区画・ 1 階店䟣 4 と住居 12 户を分譲会社が所有。

・マンションの影地は 2 筆の敷地の上にある。 1 筆の $2 / 3$ のスペースをつかい 駐車場がある。しかしその駐車場を分埕会社が経営し、使用料を徵仅して いる。分埕会社はこのスペースの土地は分誩会社所有であるため、使用料 を管理組合に納金する必要はないと主張している。登記簿では 2 筆の土地 は区分所有者全員の共有である。

・管理人室を分諢会社が第 3 者に貸し、管理組合が使用できない。なお、管 理人室には火災報知設備の受信機がついているが、管理組合が入れないの で非常時に対応できない。

・1 階空きスペースを分諆会社が尃用使用している。

・店辞部分の管理費を分㜔会社は支払わない。

当初加ら管理組合はなく、筑 20 年目にしてようやく管理組合を結成した。 しかし議決権の $1 / 3$ を分㜔会社がもっているために、初期に設定された管理 方法を変更することは難しい。裁判はしていない。

\section{5. 结論}

\section{(1)問題が生じる原因}

所有権と管理方法の初期設定によるマンションの管理上・居住上 の問題及び、具体的にどのような初期設定に問題があるかを明らか にした。本調査事例では、国の通達後に、共用部分の設定や敷地関 係の問題はみられなかったが、駐車場の専用使用権分䛊、管理組合 設立の勧奖がない、分䛊会社や元地主による管理、管理費の設定な どの問題は解消しているわけではなく、全国的に問題が生じている。 また、解決のために訴訟する例は少ない。そのため、既裁判事例は、 所有権と管理方法の初期設定によるマンションの管理上・居住上の 問題をかかえるマンションの部分的であることが推定できる。

こうした問題が生じるのは、マンション供給方法の特殊性による。 第一に、一般消費者は専有部分の購入に伴う、共用部分や敷地利用 権についての権利を不十分な理解のまま取引していることがある。 つまり、マンションの分譲という一般消費者にはわかりにくい商品 を情報の非対称性があるまま販売されている。第二に分样会社は所 有権や管理方法を入居後の管理のしやすさ・入居後の共同生活のし やすさよりも、事業性を重視し設定できることがある。また、管理 適正化のための管理組合設立支援などが義務付けられていない。第 三に管理方法などの初期設定が区分所有者間で衡平でない場合でも、 その是正が困難である。

そのため、基本的には、入居後の居住・管理上のトラブルとなる 初期設定を解消することが求められる。しかし、契約の自由に基づ きそうした設定がされる場合には、将来起こりうる問題も含めた十 分な情報開示を行うことが必要である。こうした取り組みにより、 今後供給されるマンションでは問題が解消される方向となるが、既 に生じている問題、さらには予防対応をしたにもかかわらず生じた 
問題には迅速で簡易な是正対応が必要となる。

\section{(2)問題解決のために必要な施策}

上記問題を予防、解消、解決する方法として、管理初期設定適正 化とその情報開示、迅速な紛争処理が課題となる。

一つには、分譲会社の責任として、入居後の管理が円滑に行える ように、管理組合の設立、設立総会の開催、原始規約の設定、修縜 積立金・管理費・管理会社委託契約内容の設定を義務付けることが ある ${ }^{15)}$ 。既に多くの分譲会社により実施されているが、これらが有 効に機能するには次の二条件を満たすことが必要である。第一には 入居後の区分所有者集会でそれらの設定を変更することに多数の賛 成が得られたら変更を可能とする。例えば、当初は分埕会社や分譲 会社が設定した管理会社が管理を行っても、1 年後に新たに見直す 仕組み等である。第二にはじめから特定の人が有利となるような初 期設定を行わないこと、例えば原始規約が一般の区分所有者に不利 な内容が含まれないことである。そのため、行政による指導や監督 制度が考えられる。

二つめには、共用部分と敷地の所有関係の設定とその情報開示方 法の見直しである。共用部分や敷地はその空間の持続的利用確保の 視点から共有（準共有を含む）または規約共用部分とし、初期の時 点で必ず登記すること。また、わかりやすさから図面での登記や規 約への記載、重要事項説明を行うことである。

三つめには、初期の所有権や管理方法が一般区分所有者に不利や 不具合であった場合に修正を容易にする仕組みや、それらを敏速に 解決する紛争処理機関の設置等である。

謝辞 : 調查には冨田路易氏 (当時マンション管理センター企画業務部眼)・川 瀬明美氏（当時明海大学大学院生）に協力を得ました。また全国の管理組合 の方々に調查にご協力いただきました。ここに記して関係者皆様に感謝の意 を表します。

注

1）建替えの困難性等から区分所有形式の住宅の問題が指摘されることが多い。

2）例えば駐車場の専用使用権の分䁚は、ミリオンコーポラス高峰館事件（最 高判 平成 10 年 10 月 22 日 判時 1663 号 $\quad$ p. 47) やシャルマンコーポ事 件（最高判 平成 10 年 10 月 30 日 判時 1663 号 p. 56) 共に、最高裁で は分譲会社の専用使用権の売買を㩲護している。管理人室が共用部分であ ることを争った裁判も全国で多く行われたが、判決は様々であった。その 後、平成 5 年 2 月 12 日の最高裁判決で管理人室は、100 人を超える居住者 のいるマンションでは、「管理人室は共用部分である」と判断している。

3）マンション管理適正化法の創設に当り、国土交通省マンション管理研究会 では、分変段階からの管理適正化のための社会的コントロールとして、分 謴会社の管理責任などを議論した。区分所有法改正においても、入居後の 管理円滑化の視点から、全国マンション管理組合連合会からは分誐時の初

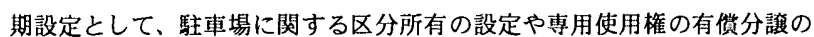
禁止について、日本弁護士連合会からは共用部分の登記、政地利用権、原 始規約の問題、駐車場尃用使用権の分䯪・留保、無偵広告塔・看板の設置、 敷地同一性の確保などの指摘が行われた。

4）区分所有法の中間試案では示されなかったが, 最終的には区分所有法 30 条 3 項で「規約は、各専有部分及び共用部分又は建物の敷地もしくは共用部 一分以外の建物の付属施設につき、その形状、面樻、位楚関係、使用目的及 び利用状況並びに各区分所有者が支払った対価その他の事情を総合的に考 虑して, 各区分所有者の利害の衡平が図られるように定めなければならな いものとする」ことが定められた。
5）参考文献 1

6）区分所有者間に共通の目標があり、对立權造がないため、解炔しやすいと いう表現とした。

7）分虽会社の協会では、分埕会社が設定する管理方法の自主規準をつくり、 社会状況をみながらレベルアップしてきている。例えば、1995 年からは協 会加入の分顡会社の物件では、必ず「長期修繥計画をつくり、それに基づ いて修繥積立金を算定する」こと、さらにマンションを分㬬する際に、「長 期修䋨計画は将来的には見值しが必要となり、建物の傷み具合によっては 状況が変わる」ことを分譲時に説明するようにしている。

8）マンション購入者が利用できる融資には、優良分埕住宅建設・購入資金融 資制度とマンション䀧入資金融資制度があり、前者の制度は全国に適用さ れ、購入者からすると融資額が大きくなるメリットがある。住宅金融公成 ではこの制度の融資条件として、分讙会社に維持管理基準を課している。 その内容は、1，管理規約案の作成と戝入者へ説明、2．長期修䋨計画案 の作成及び購入者への説明、3. 一定金額以上の修繥䅪立金額の設定 $(6000$ 円／月・戸)、4，設計図書または竣工図書の保管場所の明確化、5，募集 パンフレットによる購入者への管理内容の提示等である。分銥会社の指導 を通じて新築時にマンションの適正な管理初期設定ができるように誘道し ている。

9）都市再開発法に基づく再開発マンションの場合は、管理規約を予め知事の 許可を受けて分䜅前に設定できるため、行政による指導が行われることも ある。

10）本調查の趣旨は全国のマンションの管理組合活動を正確に把握すること にある。そのため、管理会社の立場から事実を把握するのでなく、管理組 合の立場、区分所有者の立場から把握できるように、区分所有者への閆き 取りを行った。なお、問題の把握には裁判事例を捉える方法もあるが、本 論文に示すように、裁判にまで発展するケースが多いわけではない。むし ろ各管理組合は裁判に発展させないで解决することを望む声が多い。そこ で、特に問題のあるマンションというアプローチではなく、日常的に生じ ている問題をとらえるアプローチをとった。

11) 参考文献 2.3 など

12)全国の 17 組織に開きとり調盗を実施した上で対象マンションを選定した。

13）貢貸を目的としたリースマンションやリソートマンションでは別の問題 が生じている。ここでは区分所有者自らが居住することを想定してつくら れた居住用マンションの問題をみる。

14) 実態として大規模修繥は $3 / 4$ 以上の多数の決議を取って行うことが多 かった。この点については、開取り調查後、 $1 / 2$ 以上の多数で实施でき るように区分所有法改正が行われた。また、行政による修結勧告も建築基 準法に基づき行うことはできるが、ほとんど実施されていない。

15）分䜅会社の管理費任を明確にし、それを実行する制度として、例えば、ア メリカでは管理組合創設段階ではわが国の規約にあたる宣言を分譲会社が 作成し、委諒総会までは分埕会社が管理を行う。分譩会社の管理期間は, 3 年を原則とし、所有者が $75 \%$ をすぎた場合に、60日以内に終了することに なっており、管理組合立ち上げと始動期間の支援が法で定められている。 また、韓国でも分諒会社の 1 年間の管理義務が共同住宅管理令で定められ ている(但し竣工日から9ケ月たっても入居予定者が半数に満たない場合、 過半数が入居した日から 4 ヶ月間管理を行う)。

\section{参考文献}

1）斉藤広子 ·梶浦恒男 : 米国カリフォルニア州におけるマンションの開発・ 分变・管理への行政対応, 日本マンション学会第 4 回大会研究報告集, P. $197 \sim$ P. 205, 1995. 4

2）斉藤広子・鈴木博志; 地域特性を考虑したマンション管理システム整備に 関する研究一中京圈のマンション特性と管理実態からみた地域性を考虑し たマンション管理システム整備の為にー, 日本マンション学会誌マンショ ン学第 5 号, P. 57〜P. 68, 1997. 4

3）鈴木博志・齊藤広子 : マンション供給の様態と管理の初期設定,日本建筑 学会計画系論文集第 541 号, p.177 p.184，2001.3

(2002年 7 月 19 日原稿受理， 2003 年 7 月 10 日採用決定） 